\title{
CRITICAL PRINCIPLES FOR A HOMOSEXUAL READING OF BIBLICAL TEXTS: AN INTRODUCTION
}

\author{
Lilly Nortjé-Meyer \\ Department of Biblical and Religious Studies \\ Johannesburg University
}

\begin{abstract}
Gender studies also relate to a homosexual interpretation of biblical texts. A homosexual reading of biblical texts involves the rereading and re-examination of those passages that condemn homosexuals. It is the questioning of the traditional interpretation of these passages and the identification of the heterosexism and homophobia of biblical scholars. This paper discusses the main principles involved in a homosexual reading of biblical texts.
\end{abstract}

Key Concepts: Homosexuality, Biblical perspective, authority

\section{The Word 'Homosexual'}

Human sexuality is and has always been a complicated issue. It involves physical, psychological and cultural issues (cf. Botha 2002:30-32; Malina 2002:141-150). Therefore, it is logical that our experience and understanding of sexuality has changed throughout human history. It is also evident that our own sexual experience and understanding will change during our lifetime. To try to provide simple definitions of, and explanations for, sexuality and especially homosexuality is not the aim of this article. I use the term "homosexual person/s" to refer to people who are sexually attracted to, and involved with, a person of the same sex. Homosexual people prefer to use terminology such as "gay", "queer" and "straight" (cf. Boswell 1980, 41-44) to distinguish themselves and to form a group identity. These words also refer to other issues that are not necessarily homosexual in nature. Therefore, I will not use them in this article. The term "homosexual person $/ \mathrm{s}$ " in this article refers to homosexual men, lesbian women and bisexuals. We should keep in mind that these concepts are $19^{\text {th }}$ century inventions "meant to label the dawning awareness of persons as subjective, psychological centres of awareness, as individualistic" (Malina 2002, 141).

Furthermore, to clarify "homosexual persons", we intend to include situational homosexuality. This refers to a homosexual practice under certain conditions, e.g. when people are isolated for long periods in prison or at sea, or experimental sex, or as a result of a traumatic experience or physical disorder. However, in the ancient Mediterranean world, these distinctions were not made. Same sex desires were not considered as belonging to a different kind of sexuality than heterosexuality and therefore a distinction between situational and so-called "true" homosexuality was not made. Veyne (cf. Vorster 2000:120) speaks of a legitimate "bisexuality whose manifestations seem to have been dependent on chance encounters rather than biological determinism". In contrast, "true"1 homosexuality is then considered as biologically determined and defined as an emotional and physicosexual propensity towards others of the same sex. It does not refer only to the sexual act,

"True" homosexuality is used only to distinguish the concept from occasional homosexuality. It is not used in the sense of "true" and "false". 
but also to a way of thinking, feeling and behaviour as an expression of love. Like heterosexuality, a homosexual orientation does not begin with an act or a certain feeling at a specific time. It is there from the very beginning of sexual orientation. The Bible texts did not know this homosexuality and its specific problems, but were concerned only with the commission of homosexual sexual acts (McNeil 1993:40-41).

\section{Introduction}

The statements on homosexuality in the New Testament (Rm 1:18-32; 1 Cor 6:9 and $1 \mathrm{Tm}$ 1:8-11 - mainly from Paul) are probably based on the cultic specifications in Leviticus $(18: 22,20: 13)$ and the reaction to the behaviour of idolaters from the Greco-Roman world. These statements reflect Paul's obsession with sexual purity and probably his homophobia (cf. Vorster 2000:121). Carroll (1991:81) thinks that the statements about homosexuality in the New Testament are the opinion of an individual, namely Paul, and do not necessarily reflect the meaning or attitude of the community. Neither Leviticus nor Paul can be seen as authoritative for constructing sexuality or sexual relationships for the $21^{\text {st }}$ century person. Biblical or especially the New Testament literature does not consider sexuality as the basis for defining a person's identity or for finding meaning and fulfilment in life (cf. Hays 1996:391). In any case, in antiquity, the body and sexuality were perceived negatively and would not be considered a source for providing identity and fulfilment in life. Nevertheless, these statements are "power tools" in the hands of those who are in control of the Christian religion and those sitting on the ethical power seats (cf. Nortjé-Meyer 2002:119).

Like most of the liberation movements, homosexual theology neither had its origins in the Church $^{2}$ nor in the academy, but developed from secular movements, and since the 1960s, in most Western countries at least, male and female homosexuals have become vocal advocates of their own cause. The Christian tradition and the Church were always hostile towards homosexual people who were considered sinners who needed conversion into heterosexuals. Therefore, the great theologians have written a lot on the great themes of the Bible, such as creation, sin and redemption, but when issues such as female leadership, slavery and homosexuals are discussed, they abandon the great themes and search for the single texts that refer to issues such as female leadership, slavery and homosexuals. Thus, theologians do not discuss the issue of homosexuality as a whole, but prefer to deal with it through the exegesis and analysis of the six (or seven) references in the biblical texts. "The prejudice is articulated by the method", says De Gruchy (1997:233). An example is the book of Maimela and König (1998) on the "rich variety of theologies and hermeneutics", but homosexual theology and hermeneutics are also not included.

Recently, the homosexual interpretation of biblical texts became part of the collective discipline of Gender Studies. "Gender" refers to the grammatical division of words into masculine/feminine/neuter. The feminist debate began with the demand for inclusive language because "the first deterministic understanding of language takes the androcentric cultural sex/gender language system as a self-contained closed system which signifies reality. It works with the assumption that andro-centricity (male as central, female as peripheral), exclusivity (male as focal point, female as marginal), isolation (male as self, female as other), and subjectification (male as agent and subject, female as passive object) are universal structures of language and representation" (Schüssler-Fiorenza 1992:41-42). This androcentric binary system is also reflected in socio-cultural practices and therefore homosexual people fit into the categories of being peripheral, marginal, other and passive

"The Church" refers to the universal Christian Church that believes in the Trinitarian God and considers the Bible as the authoritatively inspired word of God. 
object. Therefore, reader-response criticism used by Gender Studies includes all questions raised by people who were or are oppressed by patriarchy in the past and the present. Sadly enough, homosexual people are not always explicitly named (and therefore not included) in the lists of marginal people as Keane $(1998: 121,123)$ refers to "the painful questions concerning the elderly, handicapped people, people of colour, women, the poor and many other" as "the victims of ageism (the practice of discriminating against people on the basis of age), ableism (the lack of consideration and justice towards those with physical or mental disabilities), or racism (antagonism against people on the basis of race, or sexism (the system of discriminating against women on the basis of gender)". Same sex people are probably regarded as the "other". Even Schüssler-Fiorenza listed only slaves as marginalized men (1994:7-8).

There are very few mainstream Churches in the world that have accepted homosexuals unconditionally. A few Churches in South Africa recently took up the task of becoming involved in "meaningful dialogue with gay members" (Anthonissen and Oberholzer 2001, 84-85). But again sadly enough, the two presuppositions on which the book is based exclude the unconditional acceptance of homosexual sex relationships, the very core of homosexuality (2001:12). This is confirmed by the decision of the Dutch Reform Church's Synod and more recently the Nederduitsche Herformde Kerk van Afrika to postpone the issue for another four years.

Therefore, it is no wonder that homosexual interpretation has operated mainly from "outside" the Church, because homosexuals were not part of the Church community as homosexuals, but rather as rehabilitated heterosexuals. In this light, it is no wonder that homosexual interpretation is either revolutionary or reformist (cf. Robbins 1996:72-73). Revolutionary homosexual interpretation is almost always radical in the sense that the Bible and the Christian faith and Church tradition are so intrinsically biased and hostile towards homosexuals that these traditions have to be criticized strongly or even rejected outright (cf. Comstock 1993). Like radical feminists, they become introversionists and create an alternative homosexual community, e.g. independent homosexual Churches. This is counter-productive since it alienates itself from mainstream Churches with the result that the mainstream Churches do not have to deal with the question of same sex victims of discrimination. Reformists are mostly "homosexual friendly" theologians within the mainstream Churches who opt for a steady programme of consciousness-rising to make the Church and the Christian society aware of the effects that discrimination and injustice have on homosexual people.

\section{What is a Homosexual Reading of Biblical Texts?}

A homosexual interpretation of biblical texts as part of the gender approach shares the principles of feminist theology and black theology. The focus of homosexual interpretation and feminist theology is to depatriarchalize society and biblical texts. Patriarchy refers to the perspective of powerful male rule (i.e. restricting, limiting and excluding), mostly over women, children, homosexual people and other people who do not fit into the norms of patriarchy (cf. Loades 1998:81). The aim of feminist and homosexual interpretation is to dislodge androcentrism, which defines the heterosexual male and male experience as the norm and legitimates patriarchy. This perspective needs to be changed to a more inclusive and humane one. The shift is inextricably connected with issues of power sharing and justice for those who are oppressed because of their gender, race, sexual preference and culture. 
Homosexual people seek justice for homosexual men and women and bisexuals. Therefore, they focus on homosexual perspectives and experiences. They are suspicious of absolute truth, such as the Bible as the authoritatively inspired word of God because homosexuals are oppressed by these "absolute truths". Homosexual interpretation aims to raise the consciousness of society to the patriarchy of the received tradition and the hostility it has created towards homosexual people. Like feminists, homosexuals do this in very different ways and with different theologies and methodologies. But, it should also be remembered that homosexuals also bring their own presuppositions into biblical interpretation (Bird 1994:326-327). ${ }^{3}$

Homosexual interpretation is particularly sensitive to the complexities of society (race, class and economic status) and the impact of gender for interpretation. The ways in which human beings relate to each other do not affect only their relationship with each other, but also their relationship with God. When the Bible message is misleading, it harms not only homosexuals, but also heterosexuals. Therefore, all human beings should benefit from homosexual theology and feminist theology, not only homosexual people and women (cf. Loades 1998:82).

A homosexual reading of biblical texts involves the rereading and re-examination of the passages that condemn homosexuals. This leads to the questioning of the traditional interpretation of these passages and the identification of the heterosexism and homophobia of biblical scholars. Homosexual people are searching for positive links between the Bible and homosexuality. They are looking for a neglected word or fact that would reverse the traditional interpretations that condemn homosexuals and accept them into the Christian community without any preconditions. Homosexual people are looking for their own identity, purpose and meaning in life and they look at the Bible to help them find meaning in life. Black people's views on the Bible and sexuality in general could be important in this respect. They focus on those stories and passages in the Bible, with which they can identify and that bring hope and encouragement to their lives; stories of liberation as in the case of Exodus, David, Daniel, Jonah and Jesus. They reject any notion of "book religion" because of the way in which traditional biblical interpreters utilized the Bible to oppress people of different racial and sexual orientations and rather focus on oral traditions. The oral/aural tradition is selective about which biblical texts are interpreted. They interpret the Bible stories in a way that might shed light on their particular struggles for survival and freedom, and that affirmed their faith in a God that was for them and not against them (Douglas 1999:93).

Various attempts have been made to deal with those passages that condemn homosexuals, for example, the importance of the book Leviticus has been minimized and the cultic and cultural inappropriateness of the laws of Leviticus for today has been questioned. It has been pointed out that the sin of Sodom was not homosexuality, but the inhospitality of the inhabitants. It has been argued that Jesus said nothing about homosexuals and did therefore not categorically condemn them. Paul was not critical of homosexuals themselves, but of heterosexuals that were involved in homosexual practices. Homosexual interpreters have also argued who the references to homosexual behaviour in the Bible are pederasty and not the loving and caring relationship between two consenting adults of the same gender. These approaches and interpretations of biblical texts do not have the required influence on society to change its perceptions of homosexual people.

Homosexual interpretation is also sceptical of the patriarchal framework of biblical texts. Even the humanitarianism prescribed and encouraged in the Bible maintains the

See Bird's definition of feminism. 
power of heterosexual men over people. Taking care of a person (woman, widow, and child) is not the same as empowering the person to take care of her/himself (cf. James 1:27). Homosexual interpretation questions androcentric norms and deconstructs patriarchal structures (cf. Comstock 1993:33-36); their approach became less apologetic and more critical; they no longer seek approval in biblical texts or from the Church hierarchy, but rather looking for the shortcomings of the biblical documents.

Homosexual interpretation resists the stereotyping of homosexuals. Homosexuals consider stereotyping as lies and attempts to discredit them. They offer no apology for their sexual preferences. They rather place judgement on biblical texts and homophobic interpreters (Comstock 1993:38-43). They are fighting for personal freedom and law protection, and combating injustice against homosexuals. Comstock, one of the more critical interpreters says:

To remain within our respective Christian tradition and not challenge those passages that degrade and destroy us is to contribute to our own oppression. Those passages will be brought up and used against us again and again until Christians demand their removal from the biblical canon or, at the very least, formally discredit their authority to prescribe behaviour (1993:43).

\section{Homosexual Interpretation and the Authority of the Bible}

In ancient Greco-Roman society, the cradle of the New Testament texts, masculinity was related to being superior and active, and passivity and "being penetrated" were associated with femininity. To conduct oneself according to the role of a female was to surrender willingly to masculinity and superiority. Therefore, being superior and active was the social role for men prescribed by patriarchy (cf. Vorster 2000:120). This view is also reflected in the writings of the Bible because the Bible is a patriarchal document promoting androcentric principles (cf. Germond's discussion of malakoi and arsenokoitai in 1 Cor. 6:9

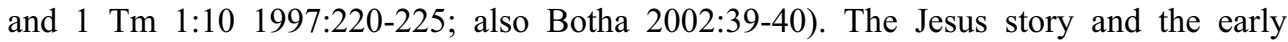
Christian story are indeed his-story without any homosexual being mentioned or referred to as being part of the Jesus or Christian movement. However, it is hardly possible that no homosexual person ever crossed the path of Jesus or was not part of the early Christian movement ${ }^{4}$. Among the marginal people who were mentioned in the gospels, homosexuals were totally absent and ignored. Therefore, homosexual interpretation is suspicious of the "absolute truth" of the Bible. If the androcentrism of the Bible and the received tradition are maintained, justice for homosexual people will never dawn.

Phyllis Bird expresses in no uncertain terms her point of view in this regard:

The Bible is a thorough patriarchal document, and no text is free from that distorting influence, even if it bears no visible imprint of patriarchy. The Bible is a product of patriarchy society, inscribing patriarchy models of faith and action in normative writings. It is also an androcentric document, viewing the world through male eyes and assuming men's experience as the norm... Its view of human nature is consequently deficient, and distorted (Bird 1994,333).

What Bird says about women and feminists is also true about homosexual people and their experiences. The negative reflections on homosexuals are inscriptions of patriarchal models of faith.

With these words of Bird, the whole issue of authority and especially the authority of the Bible comes into focus. It is not only the Bible, but also the authority of the Church that underwrites the authority of the Bible. Because the Bible is viewed as a source and instrument of oppressing women, homosexuals and other marginal people, extremists insist

According to Botha $(2002,43)$ homosexual relationships are part of all human communities and as far as we can determine, some people had homo-erotic relationships throughout all the historical periods. 
that it should be rejected along with other forms of hierarchy based on biblical principles (Bird 1994:333). Mary Daly insists that the Christian tradition is irredeemably damaging to women (Daly 1978) and we can say even more so to homosexual people. The Bible cannot function any longer as an authoritative source as long as it supports patriarchy and oppression (cf. Schüssler-Fiorenza 1985:14). This has far-reaching implications for those homosexual people whose faith has been formed by Scripture. They are torn apart by the crisis of identity and their commitment to the struggle for justice, but still want to hold on to the Bible as a source of faith that mediates the word of God to the world. The Bible somehow mediates to us a God who enables human beings to be most fully themselves (Loades 1998:81), something homosexual Christians dare not do.

Therefore, engagement with the Bible can be negative (as shown above) or positive. Positively, homosexual interpretation presupposes that the Bible is read, heard and preached as an authoritative text. "Authoritative" in this sense means the use of reason, imagination, historical insight and reflection on human experience. Although there can be no doubt that the use of biblical texts has sustained convictions about the sinfulness of homosexuality, Loades thinks there may be resources in the biblical texts to challenge those convictions (1998:81). For example, why does traditional biblical interpretation focus on single texts and not take the message of the liberation of the gospels seriously?

Homosexual interpretation could start making progress since a text is treated as a whole literary unit and not seen as bits and pieces interpreted out of context. This has given way to new methodologies and approaches such as rhetorical criticism, reader-response criticism and social historical criticism. The question is whether this text has the acclaimed authority to be redemptive to homosexuals. How could the awesome sole mastery (and supposed homophobia) of God and Jesus bring freedom or salvation to them? It is indeed in this connection that homosexual interpretation could identify with resistance to the exclusion of homosexuals and challenge the authority of biblical texts.

One of the most important feminist and gender interpreters of our day is Elisabeth Schüssler-Fiorenza. To her, revelation and authority are found in the lives of those such as the poor and the oppressed whose cause God has taken up. Central to her interpretation is the assumption that women as the Church may claim Jesus and the praxis of the earliest Church as a prototype of their own history, open to future transformation. According to her, the inconsistencies of the New Testament literature indicate that the early Christian tradition and redactional processes followed certain andocentric interests and perspectives. Therefore, the androcentric selection and transmission of early Christian traditions have manufactured the historical marginality of women. According to Schüssler-Fiorenza, the received tradition reflected in the New Testament texts is not a true and reliable reproduction of the historical reality of female leadership and participation in the early Christian movement. It seems to her that the New Testament writers were not interested in reflecting the active participation of women and slaves in the early Christian community. We can assume methodologically that the early Christian writers transmitted only a fraction of the possibly rich traditions of women's contributions to the early Christian movements (Schüssler-Fiorenza 1985:52). Therefore, to Schüssler-Fiorenza the past is not an archetype to which we must conform, but rather a prototype. She considers symbolism and the metaphors of God, ecclesiology and ministry in principle open to reconfirmation (Loades 1998:90). Schüssler-Fiorenza's method depends on an egalitarian vision of the past (biblical texts and Church history) and the present, and recovering the past as an inclusive human history (cf. Schüssler-Fiorenza 1985:54).

The problem that homosexual interpretation has with a point of view such as Schüssler- 
Fiorenza's, is that homosexual interpretation cannot depend on the earliest Christian movement where women and marginalized men like slaves were gifted with the charisms of the Holy Spirit to become leaders and then claim only later being marginalized again by the process of canonization. Homosexuals are not mentioned as being part of the earliest Christian movement. Paul's prejudice about homosexual practices in his lists of sinners in 1 Corinthians 6:9 may indicate that they were part of the earliest movement, but on condition that they were washed, sanctified and justified (1 Cor 6:11; cf. also Rm 1:24-27). This means that he wanted them to become heterosexual or to remain celibate. It can be that homosexuals were also part of the early Christian movement and received the gifts of the Spirit, but remained in the closet because of Paul's homophobia. If we follow Vorster's argument that the process of canonization did not change the position of women and marginalized men, "but it was simply the institutional culmination of a process that was probably already present in all forms of early Christianity" (2000:115), it strengthens the argument that homosexuals were not part of the early Christian movement and that the canonization process had taken nothing away from them that they never had. So, if the argument of Schüssler-Fiorenza had any use for the improvement of the position of women in the Church, it does not mean anything to the acceptance of homosexual people in the Church.

What Schüssler-Fiorenza wants so say is that the canonization process was an illegal process that undid the gospel's liberation message for women and marginalized men. Therefore, she tries to get behind the canon via historical reconstruction (1992:31-34) to get to the earliest Christian movement and uses as an authority the way in which the gospel was understood and practised. She therefore rejected the existing canon as a patriarchal product of a later stage of Church history and development. Whether the canon is a later patriarchal product or the final product of a process that began already at the very beginning of the Christian era, it is a canon in which homosexual people have no place. Therefore, it is no wonder that homosexual people discard the authority of the Bible or insist that those Bible passages that jeopardize homosexual people and women should either be removed or identified as unacceptable to the Christian faith.

The approaches of Schüssler-Fiorenza and Black Theology failed in two ways to support the formulation of principles for a homosexual interpretation of biblical texts. Firstly, Schüssler-Fiorenza's claim of women and marginalized men being part of the Christian movement from the very beginning does not apply to homosexual people. Homosexuals were excluded from the very beginning. Secondly, the homophobia of the Black community's (American and African) is even more virulent and rampant than the white heterosexual society (Douglas 1999:87-89). Therefore, to use their principles of biblical interpretation is to create a paradox that ridicules its purpose.

\section{Conclusion}

At the beginning of this article, it was stated that the Bible refers only to homosexual practices and not to the loving relationship between two adults. Paul declared in no uncertain terms that Christ was the end of the torah (cf. Rm 10:4) and therefore Paul exempted the gentile Christains from keeping the torah. It is only the sexual laws that he sustained and applied vigorously. The Church sustained this point of view unchanged for two thousand years and condemned people who placed their hope and faith in God to a living hell (cf. Cilliers 1997). The Church did not practise the message of inclusivity that lies at the heart of the Bible transcending the culturally bound messages that marginalize women, slaves and homosexual people (Germond 1997:203). The way in which traditional biblical scholars interpret the Bible cause marginalized people to state that what they have 
learned in relation to the Bible has nothing to do with God (Douglas 1999:95). In order to mitigate biblical-based homophobia, a meaningful discussion of the Bible and sexuality, especially homosexuality, will have to emerge from the homosexual community itself, from their own struggle for life and wholeness (Douglas 1999:96).

\section{BILIOGRAPHY}

Anthonissen, C and Oberholzer, P 2001. Gelowig en Gay? Riglyne vir 'n sinvolle dialoog met gay lidmate. Wellington: Lux Verbi.

Bird, P 1994. Authority and Context in the Interpretation of Biblical Texts, Neotestamentica 28(2):323-337.

Boswell, J 1980. Christianity, Social Tolerance, and Homosexuality. Gay People in Western Europe from the Beginning of the Christian Era to the Fourteenth Century. Chicago: University of Chicago Press.

Botha, PJJ 2002. Die drange van hulle hart... (Rom 1:24-27). Verbum et Ecclesia 23(1):1851.

Carrol, RP 1991. Wolf in the Sheepfold. The Bible as Problematic for Theology. London: SCM Press.

Cilliers, P 1997.'n Kas is vir klere. Kaapstad: Human and Rossouw.

Comstock, GD 1993. Gay Theology Without Apology. Cleveland: Pilgrim Press.

Daly, M 1978. God and the Rhetoric of Sexuality. London: SCM Press.

De Gruchy, Steve and Germond, Paul (eds.) 1997. Aliens in the Household of God. Homosexuality and the Christian Faith in South Africa. Cape Town: David Philip.

Douglas, KB 1999. Sexuality and the Black Church. A Womanist Perspective. Maryknoll: Orbis Book.

Germond, Paul 1997. Heterosexism, Homosexuality and the Bible, pages 188-232 in Aliens in the Household of God. Homosexuality and the Christian Faith in South Africa. Edited by Paul Germond and Steve De Gruchy. Cape Town: David Philip.

Hays, RB 1996. The Moral Vision of the New Testament. Community, Cross, New Creation. A Contemporary Introduction to New Testament Ethics. San Francisco: Harper.

Keane, M 1998. Feminist and Womanist Theology. Pages 121-135 in Initiation into Theology. The Rich Variety of Theology and Hermeneutics. Edited by S Maimela and A König. Pretoria: Van Schaik.

Loades, A 1998. Biblical Interpretation. Cambridge: Cambridge Press.

Maimela, S and König, A (eds.) 1998. Initiation into Theology. The Rich Variety of Theology and Hermeneutics. Pretoria: Van Schaik.

Malina, BJ 2002. The New Testament and Homosexuality? Part 1: The Social System behind Romans 1. Verbum et Ecclesia 23(1):141-150.

McNeil, JJ 1993. The Church and the Homosexual. $4^{\text {th }}$ ed. Boston: Beacon Press.

Nortjé-Meyer, L 2002. The Homosexual Body without Apology: A Positive Link between the Canaanite Woman in Matthew 15:21-28 and the Homosexual Interpretation of Biblical Texts. Religion and Theology 9-1/2:118-134.

Robbins, V 1996. Exploring the Texture of Texts. A Guide to Socio-rhetorical Interpretation. Valley Forge: Trinity Press. 
Schüssler-Fiorenza, E 1983. In Memory of Her. A Feminist Theological Reconstruction of Christian Origins. New York: Crossroad.

Schüssler-Fiorenza, E 1985. Toward a Feminist Biblical Hermeneutics: Biblical Interpretation and Liberation Theology. Pages 48-58 in What Christians Believe About the Bible. Edited by DK McKim. Nashville: Thomas Nelson.

Schüssler-Fiorenza, E 1992. But She said. Feminist Practices of Biblical Interpretation. Boston: Beacon Press.

Schüssler-Fiorenza, E 1994. Introduction: Transgressing Canonical Boundaries. Pages 1-14 in, Searching the Scriptures: A Feminist Commentary. Vol. 2. Edited by E Schüssler-Fiorenza. New York: Crossroad.

Vorster, JN 2000. (E)mpersonating the Bodies of Early Christianity. Neotestamentica 34(1):103-124. 